\title{
Curcumin and Cinnamaldehyde as PTP1B Inhibitors With Antidiabetic and Anticancer Potential
}

\author{
TOMASZ KOSTRZEWA, PAULINA PRZYCHODZEN, \\ MAGDALENA GORSKA-PONIKOWSKA and ALICJA KUBAN-JANKOWSKA \\ Department of Medical Chemistry, Medical University of Gdansk, Gdansk, Poland
}

\begin{abstract}
Background/Aim: Protein tyrosine phosphatase $(P T P 1 B)$ is a potential target for the treatment of type 2 diabetes and cancer. Curcumin and cinnamaldehyde have been previously reported to have antidiabetic and anticancer potentials. The aim of this study was to investigate the effect of curcumin in comparison to cinnamaldehyde on the enzymatic activity of $P T P 1 B$ and the viability of MCF-7 cancer cells. Materials and Methods: Enzymatic activity and cell viability assays were utilized. Experiments were performed using the breast cancer MCF-7 cell line. Results: Curcumin and cinnamaldehyde decreased the activity of $P T P 1 B$, and had inhibitory effects on the viability of MCF-7 cancer cells. Curcumin had a significantly higher inhibitory effect than cinnamaldehyde. Conclusion: Curcumin can be considered a potential agent for the treatment of type- 2 diabetes or cancer.
\end{abstract}

Protein tyrosine phosphatases (PTPs) are potential therapeutic targets due to their involvement in numerous disease processes, such as type- 2 diabetes and obesity or cancer development (1). PTP1B protein tyrosine phosphatase due to its role in the regulation of insulin signaling pathways has become a therapeutic target for the treatment of type- 2 diabetes (2). The role of PTP1B in the formation and development of tumors has also been already documented (3, 4). Because of the contribution of protein tyrosine phosphatases in cancer biology, they may be considered as promising targets for the development of new anticancer diagnostic and therapeutic strategies (5).

Due to its participation in the regulation of insulin signaling, PTP1B phosphatase is related with the development

Correspondence to: Alicja Kuban-Jankowska, Department of Medical Chemistry, Medical University of Gdansk, Debinki 1 Street, 80210 Gdansk, Poland. Tel: +48 583491450, Fax: +48 583491456, e-mail: alicjakuban@gumed.edu.pl

Key Words: PTP1B phosphatase, Type 2 diabetes, obesity, cancer, curcumin, cinnamaldehyde. of type-2 diabetes and obesity, which in turn predispose to the development of cancer $(6,7)$. The connection of type- 2 diabetes, as well as obesity with the induction of tumors is associated primarily with insulin resistance resulting from obesity, or further with hyperinsulinemia as a consequence of insulin resistance $(8,9)$.

PTPs were shown to be implicated in the development of glioblastomas, colon, lung, breast, stomach and multiple myeloma cancers (10). Phosphatase PTP1B has a key role in breast cancer development and pathophysiology. Many research groups observed overexpression of PTP1B phosphatase and mutations in the PTPIB gene in breast cancer cell lines $(11,12)$. PTP1B dephosphorylates tyrosine kinases responsible for the induction of breast cancer, such as HER1/EGFR, Src, JAK and STAT and initiates tumor formation (13).

Recent studies indicated that selected natural dietary compounds can be considered as potential antidiabetic and anticancer agents $(14,15)$. Moreover, some of these compounds are able to reduce PTPs activity.

Curcumin (Figure 1A) is a natural phenol present in Curcuma longa, a member of the ginger family, Zingiberaceae. Recent studies indicate that the curcumin derivative alleviates the glucose intolerance caused by obesity, giving rise to further studies on the use of curcumin compounds in the design of antidiabetic agents (16). In addition, it was found that curcumin may have inhibitory properties against PTP1B (17). Importantly, there are studies supporting that curcumin has enormous potential in the prevention and therapy of cancer $(18,19)$.

Cinnamaldehyde (Figure 1B) is a flavonoid that naturally occurs in the bark of cinnamon trees and other species of the genus Cinnamomum. Half of the essential oils of cinnamon bark is cinnamaldehyde. Studies have shown a beneficial role of cinnamaldehyde in the treatment of diabetes mellitus and its complications, as well as they suggest that cinnamaldehyde can regulate PTP1B phosphatase activity (20). Cinnamaldehyde has also reviled potency as an anticancer and chemo-preventive agent (21-23). It has been shown that cinnamaldehyde increases intracellular reactive 
oxygen species (ROS) production that lead to cancer cell death (24).

This study aimed to evaluate the inhibitory effect of curcumin and cinnamaldehyde on the activity of PTP1B phosphatase. The impact of these compounds on breast cancer cell viability was also analyzed.

\section{Materials and Methods}

Reagents. Phosphatase PTP1B (No. SRP0215) was obtained from Sigma Aldrich (Schnelldorf, Germany). MCF-7 cell line was purchased from The European Collection of Cell Cultures (ECACC). Curcumin (C1386), cinnamaldehyde (W228613), cell media, supplements and other reagents were obtained from Sigma Aldrich.

PTP1B activity assay. The solution of the recombinant PTP1B phosphatase was prepared in $10 \mathrm{mM}$ HEPES buffer, $\mathrm{pH}$ 7.4. The final concentration of phosphatase in the reaction samples was 1.5 $\mu \mathrm{g} / \mathrm{ml}(3.3 \mathrm{nM})$. Samples were untreated (control) or treated with solutions of curcumin and cinnamon aldehyde. The assay was performed in 96-well microplates, and the final volume of each sample was $200 \mu \mathrm{l}$. The enzymatic activity of phosphatase was measured at $37^{\circ} \mathrm{C}$ at $405 \mathrm{~nm}$ on a microplate reader Jupiter (Biogenet, Jozefow, Polska) with DigiRead Communication Software (Asys Hitech $\mathrm{GmbH}$ ), in the presence of $2 \mathrm{mM}$ chromogenic substrate para-nitrophenyl phosphate (pNPP)

Cell culture. The cells were cultured in DMEM medium supplemented with $10 \%$ fetal bovine serum, $100 \mu \mathrm{g} / \mathrm{ml}$ penicillin/streptomycin and $2 \mathrm{mM}$ L-glutamine. The culture was maintained at $37^{\circ} \mathrm{C}$, in an atmosphere containing $5 \% \mathrm{CO}_{2}$. The cell culture density was kept to a maximum of $1 \times 10^{6}$ cells $/ \mathrm{ml}$. At least every two days the medium was replaced with fresh medium, and the cells were counted and reseeded to maintain the recommended density.

Cell viability test. Untreated cells $\left(1 \times 10^{6}\right.$ cells $\left./ \mathrm{ml}\right)$ (control) or cells treated with solutions of curcumin and cinnamon aldehyde after the appropriate incubation time were suspended in a solution of $5 \mathrm{mg} / \mathrm{ml}$ MTT(3-(4,5-dimethylthiazol-2-yl)-2,5-diphenyltetrazolium bromide) in DMEM without phenol red. The $100 \mu \mathrm{l}$ samples were incubated for 3 to $4 \mathrm{~h}$ at $37^{\circ} \mathrm{C}$ in $96-$ well plates. When the purple precipitate was clearly visible under the microscope, $100 \mu \mathrm{l}$ of DMSO were added to each well and the plate was left in the dark for $15 \mathrm{~min}$. The absorbance at $590 \mathrm{~nm}$ was determined using a microplate reader.

Statistical analysis. The experiments were performed at least three times. The data were applied and analyzed with GraphPad Prism (GraphPad Software, v.4, La Jolla, CA, USA). Statistical analyses were performed using ANOVA combined with Tukey's test or T test combined with Wilcoxon test. The data were expressed as means \pm SD. Differences between means were considered significant for $p<0.05$.

\section{Results}

Curcumin and cinnamaldehyde decreased PTPIB enzymatic activity. An inhibitory activity assay of curcumin and cinnamaldehyde on recombinant PTP1B phosphatase was performed.<smiles>COc1cc(/C=C/C(=O)CC(=O)/C=C/c2ccc(O)c(OC)c2)ccc1O</smiles><smiles>O=C/C=C/c1ccccc1</smiles>

Figure 1. Structures of $(A)$ curcumin and (B) cinnamaldehyde.

Curcumin as well as cinnamaldehyde were able to decrease the enzymatic activity of PTP1B phosphatase. However, curcumin was much more effective than cinnamaldehyde. Curcumin was able to inhibit PTP1B in concentrations starting from $1 \mu \mathrm{M}$, with an $\mathrm{IC}_{50}$ value around $100 \mu \mathrm{M}$ (Figure 2). While $100 \mu \mathrm{M}$ cinnamaldehyde was not effective against PTP1B. Cinnamaldehyde decreased PTP1B activity in concentrations starting form $500 \mu \mathrm{M}$, with an $\mathrm{IC}_{50}$ value around $1 \mathrm{mM}$ (Figure 3 ).

Curcumin and cinnamaldehyde decreased breast cancer MCF-7 cells viability. To evaluate the effect of curcumin and cinnamaldehyde on the viability of breast cancer cells, MCF7 cells were treated with either compound. Both curcumin and cinnamaldehyde were able to decrease cell viability in a concentration dependent manner. After $24 \mathrm{~h}$ of treatment with 100 or $500 \mu \mathrm{M}$ curcumin, the viability of cells was significantly $(p<0.0001)$ decreased (Figure 4$)$. Treatment with $50 \mu \mathrm{M}$ cinnamaldehyde had a slightly smaller effect in reducing cell viability relatively to treatment with $10 \mu \mathrm{M}$ curcumin (Figures 4 and 5).

\section{Discussion}

PTP1B phosphatase, regulates insulin signaling which is related to the development of type 2 diabetes and obesity, which in turn predisposes to the development of cancer. PTP1B has become a therapeutic target in the treatment of type 2 diabetes, and its role in the formation and development of tumors has been documented (25-27).

Natural products have shown promise as potential antidiabetic agents. Moreover, the structural modifications of natural compounds could advance the generation of new clinical candidates to target PTP1B for the treatment of type-2 diabetes (28). Recent research indicates that curcumin 


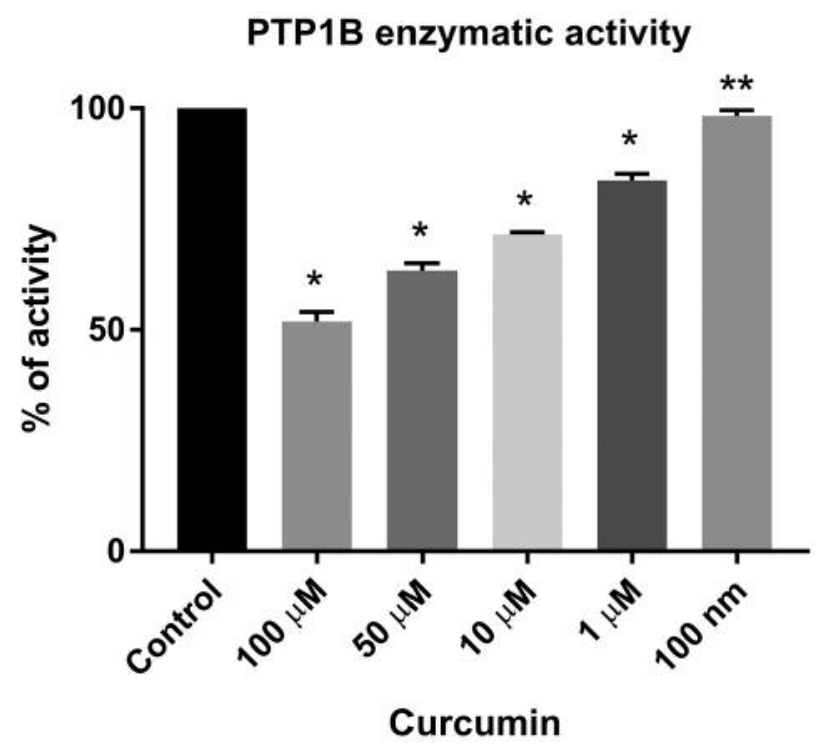

Figure 2. Enzymatic activity of PTP1B phosphatase after $60 \mathrm{~min}$ of treatment with curcumin. Data are presented as percent of the control enzymatic activity (100\%, phosphatase not treated), mean $\pm S D(n=3)$. One-way Anova test combined with Tukey test. *Means were significantly different from control $(p<0.0001)$. **Means were not significantly different from control $(p>0.05)$.

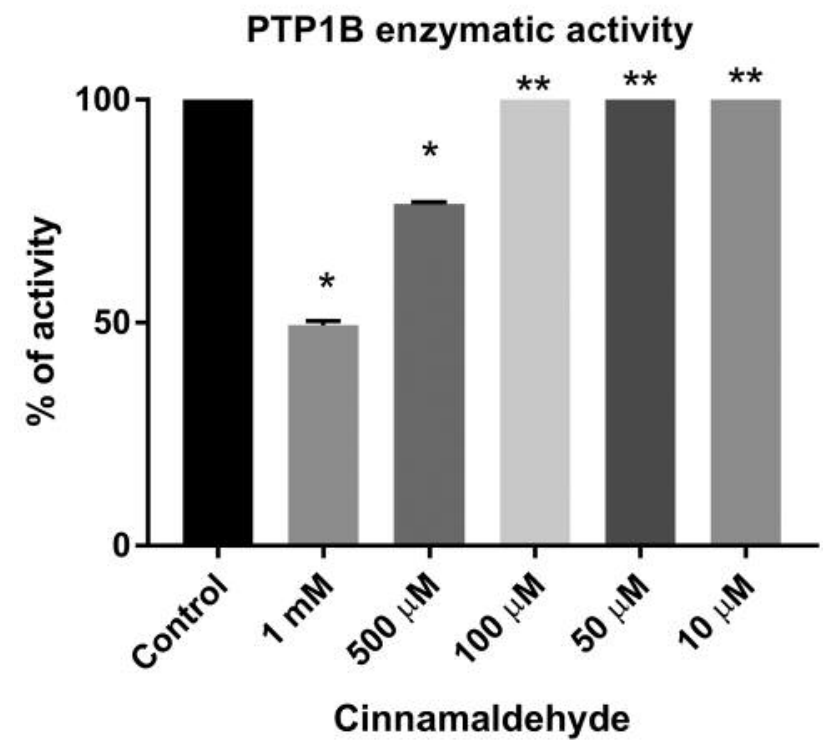

Figure 3. Enzymatic activity of PTP1B phosphatase after 60 min of treatment with cinnamaldehyde. Data are presented as percent of the control enzymatic activity (100\%, phosphatase not treated), mean $\pm S D$ $(n=3)$. One-way Anova test combined with Tukey test. $*$ Means were significantly different from control $(p<0.0001)$. **Means were not significantly different from control $(p>0.05)$.
MCF-7 cell viability $(24 h)$

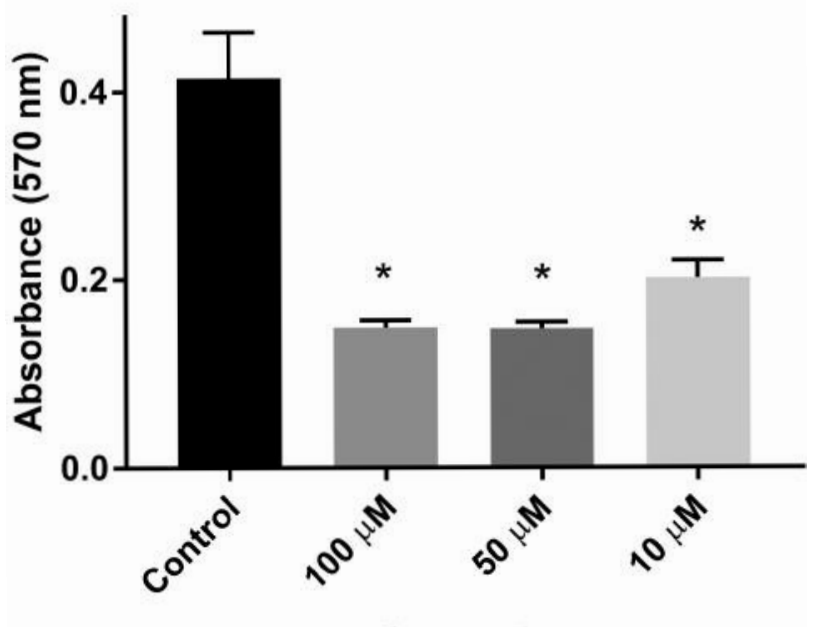

Curcumin

Figure 4. Cell viability of MCF-7 breast cancer cell line after treatment for $24 \mathrm{~h}$ with 100, 50, $10 \mu \mathrm{M}$ curcumin measured with MTT-based cell viability test. Data are presented as absorbance $(570 \mathrm{~nm})$, mean $\pm S D$ $(n=3)$. One-way Anova test combined with Tukey test. *Means significantly different from control $(p<0.0001)$.

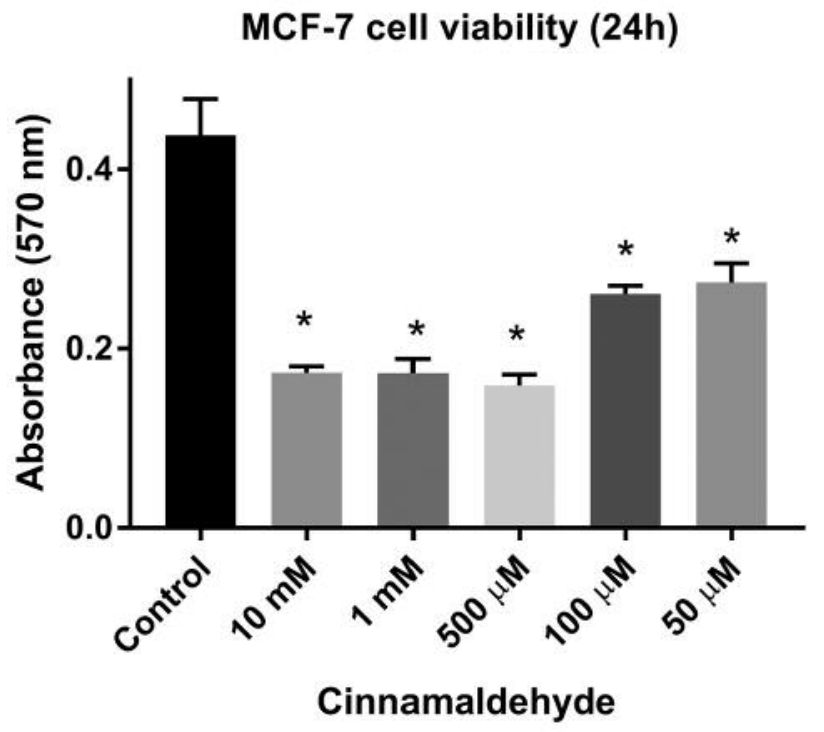

Figure 5. Cell viability of MCF-7 breast cancer cell line after treatment for $24 \mathrm{~h}$ with cinnamaldehyde measured with MTT-based cell viability test. Data are presented as absorbance $(570 \mathrm{~nm})$, mean $\pm S D(n=3)$. Oneway Anova test combined with Tukey test. *Means significantly different from control $(p<0.0001)$. 
derivatives alleviate the glucose intolerance caused by obesity, giving rise to further studies on the use of curcumin molecule in the design of antidiabetic agents (16). In addition, it was found that curcumin may have PTP1B phosphatase inhibitory properties (17). Curcumin induces apoptosis and autophagy, and also exhibits iron chelating activity in prostate cancer cells (29). Other studies have shown that curcumin also suppresses the constitutive IkB $\alpha$ phosphorylation by inhibiting IkB kinase activity (30). Epidemiological evidence suggests that phenolic antioxidants, including curcumin, protect against heart disease and cancer (31). Studies carried out so far showed a beneficial role of cinnamaldehyde in the treatment of diabetes mellitus and its complications, as well as suggest that cinnamaldehyde can regulate PTP1B phosphatase activity (20) and possess anticancer properties (22). This evidence inspires the search for other utilizations of curcumin and cinnamaldehyde compounds.

In the present study, we analyzed the inhibitory properties of curcumin and cinnamaldehyde molecules against PTP1B phosphatase and MCF-7 breast cancer cell viability. Both compounds reduced the enzymatic activity of PTP1B phosphatase, as well as MCF-7 cell viability and provide the basis for further research on their use in the design of antidiabetic and anticancer therapies. Comparing the effects of both tested compounds, we can conclude that curcumin is more effective than cinnamaldehyde and can be considered as a more potent PTP1B inhibitor.

The significance of the type- 2 diabetes global public health problem in present times is underlined by the worldwide increasing childhood obesity cases, which have more than doubled since 1980 (32). Type-2 diabetes increases the risk for cardio-metabolic diseases and cancer development in adulthood. Recent data have shown a strong association between higher body mass index and increased risk for several malignancies such as leukemia, colorectal or breast cancer $(33,34)$. As PTP1B phosphatase is implicated in both obesity and type- 2 diabetes, as well as cancer development, targeting its enzymatic activity is a promising strategy in the design of treatments for these pathologies. Moreover, knowledge about the preventive effects of natural products could be utilized in choosing a diet for people with these disorders.

In conclusion, the key contribution of protein tyrosine phosphatases in cancer biology indicates that they can be promising targets for the development of new therapeutics. Due to the inhibitory properties of curcumin and cinnamaldehyde molecules against protein tyrosine phosphatases implicated in diabetes and cancer development, they can be utilized to design potential antidiabetic and anticancer therapies.

\section{Conflicts of Interest}

The Authors declare that they have no conflict of interest regarding this study.

\section{Acknowledgements}

This work was supported by MN Grant No. 01-0275/08/259 from Medical University of Gdansk and Ministry of Science and Higher Education.

\section{References}

1 Li L and Dixon JE: Form, function, and regulation of protein tyrosine phosphatases and their involvement in human diseases. Semin Immunol 12: 75-84, 2000.

2 Koren $\mathrm{S}$ and Fantus IG: Inhibition of the protein tyrosine phosphatase PTP1B: potential therapy for obesity, insulin resistance and type-2 diabetes mellitus. Best Pract Res Clin Endocrinol Metab 21: 621-640, 2007.

3 Nee BG and Tonks NK: Protein tyrosine phosphatases in cancer. Anticancer Res 37: 365, 2017.

4 Tasneem $M$ and Samson TJ: Role of protein tyrosine phosphatases in cancer. Prog Nucleic Acid Res Mol Biol 81: 297-329, 2006.

5 Scott LM, Lawrence HR, Sebti SM, Lawrence NJ and Wu J: Targeting protein tyrosine phosphatases for anticancer drug discovery. Curr Pharm Des 16: 1843-1862, 2010.

6 Seely BL, Staubs PA, Reichart DR, Berhanu P, Milarski KL, Saltiel AR, Kusari J and Olefsky JM: Protein tyrosine phosphatase 1B interacts with the activated insulin receptor. Diabetes 45: 1379-1385, 1996.

7 Elchebly M, Payette P, Michaliszyn E, Cromlish W, Collins S, Loy AL, Normandin D, Cheng A, Himms-Hagen J, Chan CC, Ramachandran C, Gresser MJ, Tremblay ML and Kennedy BP: Increased insulin sensitivity and obesity resistance in mice lacking the protein tyrosine phosphatase-1B gene. Science 283 : 1544-1548, 1999.

8 Calle EE and Kaaks R: Overweight, obesity and cancer epidemiological evidence and proposed mechanisms. Nat Rev Cancer 4: 579-591, 2004.

9 Renehan AG, Roberts DL and Dive C: Obesity and cancer: pathophysiological and biological mechanisms. Arch Physiol Biochem 114: 71-83, 2008 .

10 Hendriks WJAJ and Bohmer FD: Non-transmembrame PTPs in cancer. In: Protein Tyrosine Phosphatases in Cancer. BG Neel and NK Tonks (eds.). Springer, New York, 2016.

11 Balavenkatraman KK, Aceto N, Britschgi A, Mueller U, Bence $\mathrm{KK}$, Neel BG and BentiresAlj M: Epithelial protein-tyrosine phosphatase $1 \mathrm{~B}$ contributes to the induction of mammary tumors by HER2/Neu but is not essential for tumor maintenance. Mol Cancer Res 9: 1377-1384, 2011.

12 Aceto $\mathrm{N}$ and Bentires-Alj M: Targeting protein-tyrosine phosphatases in breast cancer. Oncotarget 3: 514-515, 2012.

13 Nunes-Xavier CE, Martín-Pérez J, Elson A and Pulido R: Protein tyrosine phosphatases as novel targets in breast cancer therapy. Biochim Biophys Acta 1836: 211-226, 2013.

14 Park J and Jang HJ: Anti-diabetic effects of natural products an overview of therapeutic strategies. Mol Cell Toxicol 13: 1, 2017.

15 Nobili S, Lippi D, Witort E, Donnini M, Bausi L, Mini E and Capaccioli S: Natural compounds for cancer treatment and prevention. Pharmacol Res 59: 365-378, 2009.

16 Panzhinskiy E, Hua Y, Lapchak PA, Topchiy E, Lehmann TE, Ren J and Nair SE: Novel curcumin derivative CNB-001 
mitigates obesity-associated insulin resistance. J Pharmacol Exp Ther 349: 248-257, 2014.

17 Li JM, Li YC, Kong LD and Hu QH: Curcumin inhibits hepatic protein-tyrosine phosphatase $1 \mathrm{~B}$ and prevents hypertriglyceridemia and hepatic steatosis in fructose-fed rats. Hepatology 51: 1555-1566, 2010.

18 Aggarwal BB, Kumar A and Bharti AC: Anticancer potential of curcumin: preclinical and clinical studies. Anticancer Res 23: 363-398, 2003.

19 Vallianou NG, Evangelopoulos A, Schizas N and Kazazis C: potential anticancer properties and mechanisms of action of curcumin. Anticancer Res 35: 645-651, 2015.

20 Zhu R, Liu H, Liu C, Wang L, Ma R, Chen B, Li L, Niu J, Fu $\mathrm{M}$, Zhang D and Gao S: Cinnamaldehyde in diabetes: A review of pharmacology, pharmacokinetics and safety. Pharmacol Res 122: 78-89, 2017.

21 Larasati YA and Meiyanto E: Revealing the potency of cinnamon as an anti-cancer and chemopreventive agent. IJCC 9: 47-62, 2018 .

22 Hong SH, Ismail IA, Kang SM, Han DC and Kwon BM: Cinnamaldehydes in Cancer Chemotherapy. Phytother Res 30: 754-767, 2016.

23 Li J, Teng Y, Liu S, Wang Z, Chen Y, Zhang Y, Xi S, Xu S, Wang $\mathrm{R}$ and Zou $\mathrm{X}$ : Cinnamaldehyde affects the biological behavior of human colorectal cancer cells and induces apoptosis via inhibition of the PI3K/Akt signaling pathway. Oncol Rep 35: 1501-1510, 2016.

24 Cabello CM, Bair WB, Lamore SD, Ley S, Bause AS, Azimian $S$ and Wondrak GT: The cinnamon-derived Michael acceptor cinnamic aldehyde impairs melanoma cell proliferation, invasiveness, and tumor growth. Free Radic Biol Med 46: 220231, 2009.

25 Frankson R, Yu ZH, Bai Y, Li Q, Zhang RY and Zhang Z: Therapeutic targeting of oncogenic tyrosine phosphatases. Cancer Res 77: 5701-5705, 2017.

26 Bollu LR, Mazumdar A, Savage MI and Brown PH: molecular pathways: Targeting protein tyrosine phosphatases in cancer. Clin Cancer Res 23: 2136-2142, 2017.
27 Hoekstra E, Das AM, Swets M, Cao W, van der Woude CJ, Bruno MJ, Peppelenbosch MP, Kuppen PJ, Ten Hagen TL and Fuhler GM: Increased PTP1B expression and phosphatase activity in colorectal cancer results in a more invasive phenotype and worse patient outcome. Oncotarget 7: 21922-21938, 2016.

28 Khalaf RA: Exploring natural products as a source for antidiabetic lead compounds and possible lead optimization. Curr Top Med Chem 16: 2549-2561, 2016.

29 Chunguang Y, Xueyou M, Zhihua W, Xing Z, Zhiquan H, Zhangqun $Y$ and Guanxin S: curcumin induces apoptosis and protective autophagy in castration-resistant prostate cancer cells through iron chelation. Drug Des Devel Ther 11: 431-439, 2017.

30 Bharti, AC, Donato N, Singh S, Aggarwal BB, Nordan RP and Siegel DS: Curcumin (diferuloylmethane) down-regulates the constitutive activation of nuclear factor- $\mathrm{\kappa B}$ and ІкВ $\alpha$ kinase in human multiple myeloma cells, leading to suppression of proliferation and induction of apoptosis. Blood 101: 1053-1062, 2003.

31 Elattar TM and Virji AS: The inhibitory effect of curcumin, genistein, quercetin and cisplatin on the growth of oral cancer cells in vitro. Anticancer Res 20: 1733-1738, 2000.

32 Weihrauch-Blüher S, Schwarz P and Klusmann JH: Childhood obesity: increased risk for cardiometabolic disease and cancer in adulthood. Metabolism pii: S0026-0495(18)30255-5, 2018.

33 Lauby-Secretan B, Scoccianti C, Loomis D, Grosse Y, Bianchini $\mathrm{F}$ and Straif K: Body fatness and cancer - viewpoint of the IARC working group. N Engl J Med 375: 794-798, 2016.

34 Shamriz O, Leiba M, Levine H, Derazne E, Keinan-Boker L and Kark JD: Higher body mass index in 16-19 year-old Israeli adolescents of North African, Middle Eastern, and European origins is a predictor of acute myeloid leukemia: a cohort of 2.3 million Israelis. Cancer Causes Control 28: 331-339, 2017.

Received November 20, 2018

Revised December 16, 2018

Accepted December 17, 2018 